\title{
Alkali-Activated Binder Based on Milled Antigorite
}

\author{
Elena V. Kalinkina, Basya I. Gurevich and Alexander M. Kalinkin * \\ Tananaev Institute of Chemistry-Subdivision of the Federal Research Centre, Kola Science Centre of the Russian \\ Academy of Sciences, Akademgorodok 26a, 184209 Apatity, Murmansk Region, Russia; \\ kalinkina@chemy.kolasc.net.ru (E.V.K.); gurevich1931@yandex.ru (B.I.G.) \\ * Correspondence: kalinkin@chemy.kolasc.net.ru; Tel.: +7-81555-79523
}

Received: 29 September 2018; Accepted: 2 November 2018; Published: 4 November 2018

check for updates

\begin{abstract}
Antigorite is a very common rock-forming mineral and it is often present in mining wastes. Utilization of these wastes is a very important issue from the environmental point of view. A potential use for mining wastes is for the production of building materials. This study investigated the alkali activation of antigorite and antigorite-containing ore dressing tailings (AT) milled in a planetary ball mill in an air or $\mathrm{CO}_{2}$ atmosphere. The specific surface area, amorphisation, and dehydroxylation of milled antigorite and AT were examined, and their effect on the cementitious properties was investigated. Binders were prepared by mixing the milled antigorite or AT with liquid glass and curing at $20 \pm 2{ }^{\circ} \mathrm{C}$ in dry (relative humidity of $65 \pm 5 \%$ ) or humid (relative humidity of $95 \pm 5 \%$ ) conditions for up to 28 days. Curing at dry conditions was found to produce binders with increased strengths. The compressive strength of the alkali-activated binder also increased with increased milling time. For AT milled in air for $4 \mathrm{~min}$ and cured in dry conditions for 28 days, the compressive strength was $49 \mathrm{MPa}$. The milling atmosphere (air or $\mathrm{CO}_{2}$ ) influenced the cementitious properties of the alkali activated binder to a small extent.
\end{abstract}

Keywords: antigorite; ore dressing tailings; mechanical activation; alkali-activated binder

\section{Introduction}

Antigorite, along with lizardite and chrysotile, is one of the major polymorphs of the serpentine group with ideal composition of $\mathrm{Mg}_{3} \mathrm{Si}_{2} \mathrm{O}_{5}(\mathrm{OH})_{4}$. These hydrated, 1:1 layered magnesium-rich silicates are very common rock-forming minerals. Their crystal structures-which consist of alternating tetrahedral (silica-like) and octahedral (brucite-like) sheets-are essentially the same, differing only in the curvature of the lattice planes [1].

Large amounts of serpentine minerals are often present in mining wastes (overburden rocks, ore dressing tailings and so on), including waste from copper and nickel mines [2,3]. In fact, the ore dressing tailings of the Pechenganickel works (JSC Kola Mining and Metallurgical Company, Murmansk Region, Russia) typically contain an average of $60 \%$ serpentine (mainly in the form of antigorite) [4]. Considering that the total volume of the accumulated tailings is around $250 \mathrm{Mt}$ [5], the amount of serpentine in them can be estimated to be $150 \mathrm{Mt}$. Utilization of the ore dressing tailings of the Pechenganickel works is a very important issue from an environmental point of view $[4,5]$.

A potential use for mining waste is for the production of building materials. It has long been known that thermal treatment of inert serpentinite confers cementitious properties to the ground rock [6]. Heating serpentinite in specific conditions $\left(500-700{ }^{\circ} \mathrm{C}\right)$ results in dehydroxylation, amorphisation and the formation of reactive metastable phases. However, overheating leads to crystallisation of forsterite and enstatite, as well as loss of hydraulic activity. It should be noted that cements based on thermally-treated serpentine have not yet found a wide practical application. This is mainly due to the fact that achieving the desired binding properties requires the calcination of large 
volumes of raw materials within a narrow temperature range (depending on serpentinite composition), with strictly fixed residence. Recently, the increased reactivity of dehydroxylated serpentine minerals has been extensively studied with respect to their aqueous dissolution and carbonation (reviewed in $[7,8])$. This research has been driven by current interests in the extraction of metals from serpentine, and the reduction of anthropogenic $\mathrm{CO}_{2}$ emissions. Mechanical activation of serpentine and other kinds of pre-treatment can have similar effects as thermal treatment with regards to dehydroxylation and reactivity [7-12].

A promising pathway for the preparation of binders from industrial waste is alkali-activation technology. During the last two decades, this technology has played an increasingly important part in the development of novel, eco-friendly alternatives to Portland cement. Alkali-activated materials are binder systems that can be prepared by the reaction of ground silicate (aluminosilicate) with an alkali agent (for example, sodium hydroxide solution or soluble sodium silicate). Geopolymers-such as ones based on class F fly ashes and calcined clays-are regarded as a subclass of alkali-activated materials, and are synthesised almost exclusively from aluminosilicate powder with low contents of calcium and other divalent and trivalent metals such as magnesium and iron [13-15]. A large body of research has shown that alkali-activated binders based on various industrial wastes often display comparable or even higher physical-mechanical and other properties-as well as a notably lower $\mathrm{CO}_{2}$ footprint-than conventional Portland cement [16-24].

To our knowledge, no previous research has investigated alkali-activated materials based on serpentine minerals. In the present study, we investigated the cementitious properties of antigorite as a component of alkali-activated binder. Because of the low hydraulic activity of serpentine, we employed a pre-treatment step of mechanical activation. The efficiency of mechanical activation for increasing the reactivity of solids is well established [25-28], and is a particularly effective technique for improving the mechanical properties of alkali-activated materials [29-35]. The term "mechanical activation" (MA) in this paper refers to the structural-chemical changes on the surface and in the bulk of minerals caused by milling.

Previous studies have revealed that $\mathrm{Ca}$ - and $\mathrm{Mg}$-containing silicates-including serpentinechemisorb considerable amounts of atmospheric $\mathrm{CO}_{2}$ (up to $10-12 \mathrm{wt}$. \%) in the form of carbonate ions during prolonged grinding in air in a mortar grinder [36,37]. The carbonisation of silicates is notably increased if $\mathrm{MA}$ is carried out in a pure $\mathrm{CO}_{2}$ atmosphere [38-40]. It has also been shown that MA of magnesia ferriferous $\mathrm{Cu}-\mathrm{Ni}$ slag in $\mathrm{CO}_{2}$ resulted in an alkali-activated slag binder with higher compressive strength compared with that produced using MA in air [41]. The aim of this study was to investigate the influence of MA on the alkaline-activation behaviour of antigorite and antigorite-containing ore dressing tailings. The MA was carried out in both air and in $\mathrm{CO}_{2}$ atmospheres in order to elucidate the influence of carbonisation on the binding properties of antigorite.

\section{Materials and Methods}

\subsection{Mineral Samples and Preparation}

Monomineral samples of antigorite $(>98 \%)$ were obtained from the Pilgujärvi massif of the Kola Peninsula, and copper-nickel ore dressing tailings were obtained from the Pechenganickel works (JSC Kola Mining and Metallurgical Company, Murmansk Region, Russia). Antigorite was crushed and hand-picked to remove identifiable impurities and analysed using X-ray diffraction (XRD). It was then ground and sieved with a $250 \mu \mathrm{m}$ mesh. This sample is referred to as initial antigorite. The antigorite-containing ore dressing tailings, hereafter referred as AT, contained $\sim 70$ wt. \% serpentine (mainly in the form of antigorite); 10-15 wt. \% talc; 10-15 wt. \% olivine, pyroxenes, amphiboles and magnetite and minor amounts of carbonate minerals and sulphides (pyrrhotite, pentlandite and chalcopyrite). The Brunauer-Emmett-Teller (BET) surface areas of initial antigorite and AT were 1.63 and $1.44 \mathrm{~m}^{2} / \mathrm{g}$, respectively. The chemical compositions of antigorite and AT are given in Table 1. 
Table 1. Chemical composition of antigorite and antigorite-containing ore dressing tailings (AT) (wt. \%).

\begin{tabular}{ccccccccccccc}
\hline $\begin{array}{c}\text { Mineral } \\
\text { Component }\end{array}$ & $\mathrm{SiO}_{2}$ & $\mathrm{MgO}$ & $\mathrm{Fe}_{2} \mathrm{O}_{3}$ & $\mathrm{FeO}$ & $\mathrm{CaO}$ & $\mathrm{Al}_{2} \mathrm{O}_{3}$ & $\mathrm{NiO}$ & $\mathrm{Na}_{2} \mathrm{O}$ & $\mathrm{K}_{2} \mathrm{O}$ & $\mathrm{MnO}$ & $\mathrm{CO}_{2}$ & $\mathrm{LOI}$ \\
\hline $\begin{array}{c}\text { Antigorite } \\
\text { AT }\end{array}$ & 38.74 & 33.82 & 3.99 & 8.83 & 0.66 & 1.29 & 0.04 & 0.06 & 0.05 & 0.19 & 0.13 & 11.4 \\
\hline
\end{tabular}

\subsection{Mechanical Activation}

Mechanical activation was carried out in an AGO-2 laboratory planetary mill (Novic, Novosibirsk, Russia) [26] at a centrifugal force of $40 \mathrm{~g}$ in an air or $\mathrm{CO}_{2}$ atmosphere. Steel balls $8 \mathrm{~mm}$ in diameter were used as milling bodies. For the majority of experiments, the ratio of the mass of steels balls to the mass of mineral sample was six ( $240 \mathrm{~g}$ of steels balls and $40 \mathrm{~g}$ of mineral sample). These conditions are referred to as moderate conditions of MA. In order to study the BET surface area of antigorite as a function of milling time under more intensive mechanical treatment, several experiments were carried out changing the ratio of the mass of steel balls to the mass of mineral to 20 (referred to as hard conditions of MA). All other experiments employed moderate milling conditions. MA was carried out batchwise for different periods of time, ranging from $30 \mathrm{~s}$ to $600 \mathrm{~s}$.

Prior to $\mathrm{MA}$ in a $\mathrm{CO}_{2}$ atmosphere, the grinding vial containing the balls and sample was purged with a slow jet of $\mathrm{CO}_{2}$ to displace all air. The moisture content of $\mathrm{CO}_{2}$ was less than 0.05 vol. \%. Every $60 \mathrm{~s}$, the mill was stopped and any powder sticking to the vial was scraped off and mixed thoroughly with a spatula. Milling was resumed after refilling the vial with $\mathrm{CO}_{2}$.

\subsection{Powder Characterisation}

Analysis by XRD was performed using a XRD 6000 diffractometer (Shimadzu Corporation, Tokyo, Japan) with $\mathrm{Cu}-\mathrm{K} \alpha$ radiation; 2-theta/step size: $0.02^{\circ}$; dwell time: $1 \mathrm{~s}$. Fourier transform infrared (FT-IR) transmission spectra were recorded with a Nicolet 6700 FTIR spectrometer (Thermo Electron Scientific Instruments Corporation, Madison, WI, USA) using potassium bromide tablets. The carbon contents of the slag samples were determined using an ELTRA CS-2000 analyser (ELTRA GmbH, Haan, Germany). The specific surface area was measured using the standard Blaine test and nitrogen BET method with a Flow-Sorb II 2300 instrument (Micromeritics, Norcross, GA, USA). The thermal analyses of differential thermal analysis (DTA) and thermogravity (TG) measurements were performed on a STA 409 PC/PG Luxx ${ }^{\circledR}$ instrument (NETZSCH, Selb, Germany), heating the samples at a rate of $10^{\circ} \mathrm{C} / \mathrm{min}$ in an alumina crucible under argon.

\subsection{Leaching Analysis}

Leaching analyses were performed by mixing mechanically activated antigorite or AT with distilled water or $2 \mathrm{M}$ and $5 \mathrm{M} \mathrm{NaOH}$ solution at a mineral:liquid ratio of 1:40, and then stirring continuously for $5 \mathrm{~h}$ at $22 \pm 2{ }^{\circ} \mathrm{C}$. After filtration, the concentrations of elements in solution were determined with an Optima 8300 ICP-OES Spectrometer (PerkinElmer, Inc., Waltham, MA, USA).

\subsection{Preparation and Characterisation of Alkali-Activated Binders}

Milled antigorite or AT was mixed with sodium silicate solution ("liquid glass") and distilled water by hand for three minutes, resulting in a paste with plastic consistency. The amount of liquid glass added was expressed by amount of $\mathrm{Na}_{2} \mathrm{O}$ in liquid glass relative to the amount of mineral component, wt. \%. The water content was adjusted to give the same workability of the pastes; therefore, the water content varies. Water to solid ratio $(\mathrm{w} / \mathrm{s})$ was defined without considering water present in the liquid glass. Characteristics of sodium silicate solutions are as follows: (1) solid content of $45.2 \%$ with $\mathrm{SiO}_{2}=31.0 \%, \mathrm{Na}_{2} \mathrm{O}=14.2 \%$ and a silica modulus (molar ratio of $\mathrm{SiO}_{2} / \mathrm{Na}_{2} \mathrm{O}$ in liquid glass) of 2.25; (2) solid content of $40.7 \%$ with $\mathrm{SiO}_{2}=30.7 \%, \mathrm{Na}_{2} \mathrm{O}=10.0 \%$ and a silica modulus of 3.18. Examples of mixture compositions are given in Table 2. 
Table 2. Examples of mixture compositions.

\begin{tabular}{|c|c|c|c|c|c|c|c|}
\hline \multirow{2}{*}{$\begin{array}{c}\text { Mineral } \\
\text { Component }\end{array}$} & \multirow{2}{*}{$\begin{array}{l}\text { Milling } \\
\text { Time, s }\end{array}$} & \multicolumn{2}{|c|}{ Liquid Glass } & \multirow[b]{2}{*}{$\mathbf{w} / \mathbf{s}$} & \multicolumn{3}{|c|}{ Paste Composition, wt. \% } \\
\hline & & $\% \mathrm{Na}_{2} \mathrm{O} *$ & $\begin{array}{c}\text { Silica } \\
\text { Modulus }\end{array}$ & & $\begin{array}{c}\text { Mineral } \\
\text { Component }\end{array}$ & $\begin{array}{l}\text { Liquid } \\
\text { Glass }\end{array}$ & $\begin{array}{l}\text { Added } \\
\text { Water }\end{array}$ \\
\hline Antigorite & 600 & 3.0 & 2.25 & 0.26 & 67.97 & 14.36 & 17.67 \\
\hline $\mathrm{AT}^{* *}$ & 600 & 3.0 & 2.25 & 0.22 & 69.87 & 14.76 & 15.37 \\
\hline AT & 240 & 4.0 & 3.18 & 0.25 & 60.53 & 24.33 & 15.14 \\
\hline
\end{tabular}

${ }^{*}$ Amount of $\mathrm{Na}_{2} \mathrm{O}$ in liquid glass relative to the amount of mineral component, wt. \%. ${ }^{* *}$ Antigorite-containing ore dressing tailings.

The pastes were cast into $1.41 \times 1.41 \times 1.41 \mathrm{~cm}^{3}$ cubic molds. Prepared specimens were cured in a relative humidity of $65 \pm 5 \%$ (referred to as dry conditions) or $95 \pm 5 \%$ (referred to as humid conditions) at $22 \pm 2{ }^{\circ} \mathrm{C}$ for $24 \mathrm{~h}$. After demolding, the specimens were further cured to testing time in the same condition as applied in the first $24 \mathrm{~h}$. Compressive strength data were obtained from an average of 3 samples in 1, 7 and 28 days.

\section{Results and Discussion}

\subsection{Effect of Mechanical Activation on Antigorite and AT}

\subsubsection{BET Specific Surface Area}

The effects of milling time and conditions on the BET specific surface area $\left(S_{s p}\right)$ of antigorite and AT are shown in Figure 1. When moderate MA was carried out in air, the $S_{s p}$ continuously increased, reaching $30 \mathrm{~m}^{2} / \mathrm{g}$ and $23 \mathrm{~m}^{2} / \mathrm{g}$ by $600 \mathrm{~s}$ of milling for antigorite and AT, respectively. The lower $S_{s p}$ of $\mathrm{AT}$ is likely to be related to the difference in the mineral composition.

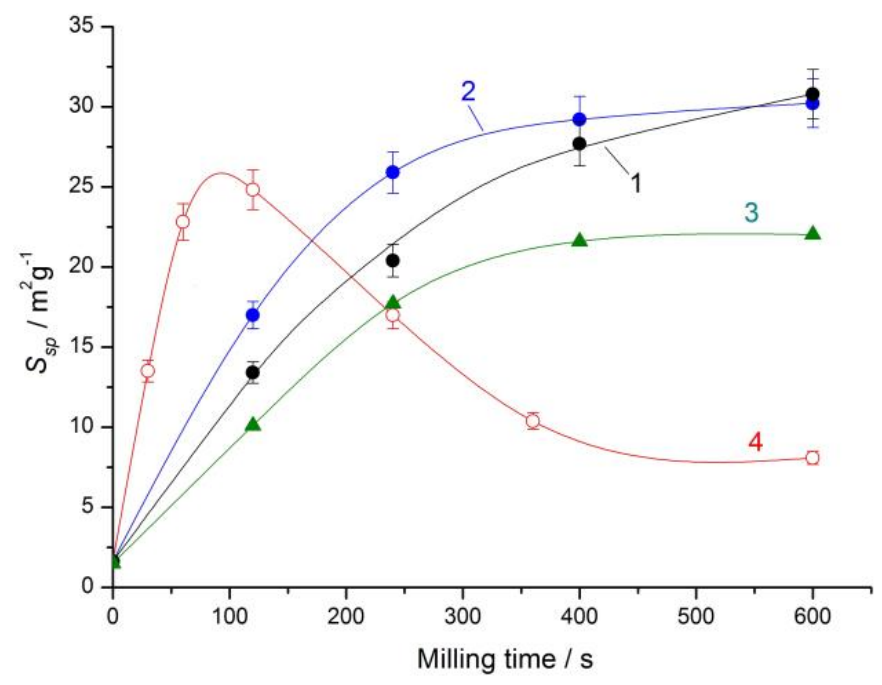

Figure 1. Specific surface areas of antigorite and antigorite-containing ore dressing tailings (AT) as a function of milling time. Curves 1 and 2: moderate mechanical activation (MA) of antigorite in air and $\mathrm{CO}_{2}$, respectively; 3: moderate MA of AT in air; 4: hard MA of antigorite in air.

The $S_{s p}$ of antigorite was higher in the first few minutes of MA when the mineral was milled using moderate conditions in $\mathrm{CO}_{2}$ than when milling was carried out in air (Figure 1). The $S_{s p}$ values converged with increased milling time, to be almost equivalent by $10 \mathrm{~min}$. Therefore, the $S_{s p}$ of antigorite has some dependence on the milling atmosphere. The measured carbon contents of antigorite samples milled for $600 \mathrm{~s}$ in air and in $\mathrm{CO}_{2}$ were 0.17 and $0.81 \%$, respectively. 
It is well established that the particle size decrease that occurs during intensive MA results in the following effects: (i) irreversible plastic deformations of the particles' surface layers leading to the formation of structural defects; (ii) strengthening of the particles due to unfavourable conditions for crack formation; (iii) reduction of the energy of milling bodies due to increased inter-particle contacts and initiation of viscous behaviour of a fine powder; and (iv) aggregation of particles. As a result, with increased milling time, the rate of aggregation becomes equal to the rate of disintegration, at which point $S_{s p}$ reaches the highest value obtainable in experimental conditions [25,26,42]. It can be seen from Figure 1 that, during moderate conditions of MA (curves 1, 2 and 3), the $S_{s p}$ values approached their maximum values within 8-10 min of milling. However, when hard MA of antigorite was carried out in air, the $S_{s p}$ increased sharply to reach $\sim 25 \mathrm{~m}^{2} / \mathrm{g}$ in the first $2 \mathrm{~min}$, then decreased gradually to reach $\sim 8 \mathrm{~m}^{2} / \mathrm{g}$ by $10 \mathrm{~min}$ (Figure 1, curve 4 ). This can be explained by acceleration of the above-mentioned processes leading to particle aggregation outweighing disintegration after $2 \mathrm{~min}$ of MA. A similar dependence of the $S_{s p}$ has been reported for serpentine milled in air for $240 \mathrm{~min}$ in a Fritsch Pulverissette-7 planetary mill ( $3 \mathrm{~g}$ of the sample were milled with 7 agate balls of $15 \mathrm{~mm}$ diameter; the rotational speed of the mill was $700 \mathrm{rpm}$ ) [12].

\subsubsection{X-Ray Diffraction}

The XRD data revealed that MA of antigorite in air resulted in disorder of the mineral lattice predominantly along the $\mathrm{c}$ axis, as the largest decrease of intensity was observed for the (001) reflection at $2 \theta=12.20^{\circ}$ (Figure 2). This is in line with the results of Drief and Nieto, who studied structural changes of antigorite following MA in a vibrational mill [10].

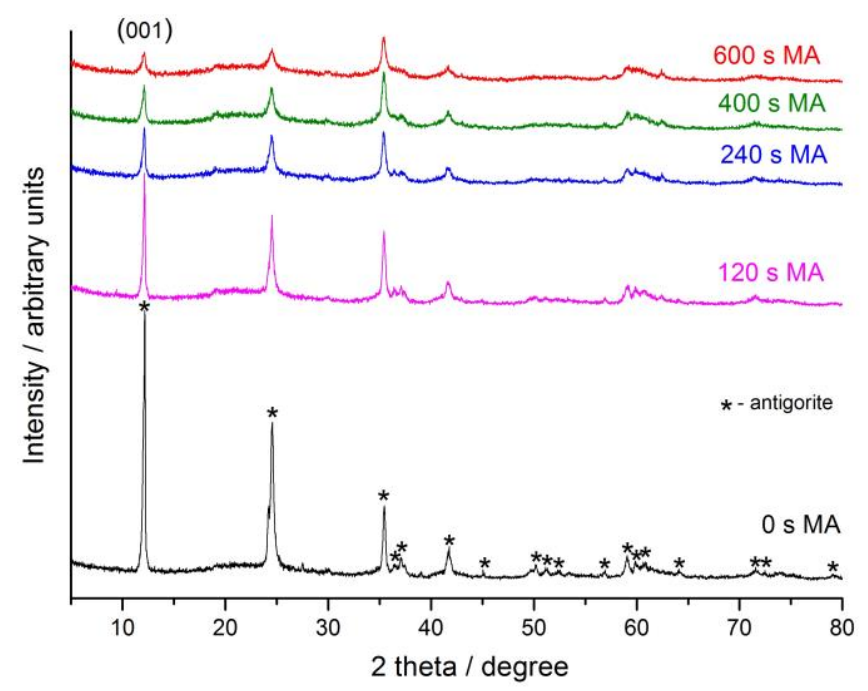

Figure 2. The X-ray diffraction patterns of initial antigorite ( 0 s MA) and antigorite that had been milled in air in moderate conditions.

The degree of amorphisation of antigorite $\left(D_{a m}\right)$ was calculated from the peak areas corresponding to (001) reflection of initial antigorite $\left(A_{0}\right)$ and mechanically activated antigorite $\left(A_{M A}\right)$ according to Equation (1):

$$
D_{a m}=\left(1-\frac{A_{M A}}{A_{0}}\right) \cdot 100 \% .
$$

From Figure 3, it can be seen that $D_{a m}$ increased rapidly to $~ 70 \%$ during the first $200 \mathrm{~s}$ of MA. The $D_{a m}$ continued to increase smoothly, reaching $\sim 85 \%$ by $600 \mathrm{~s}$. 


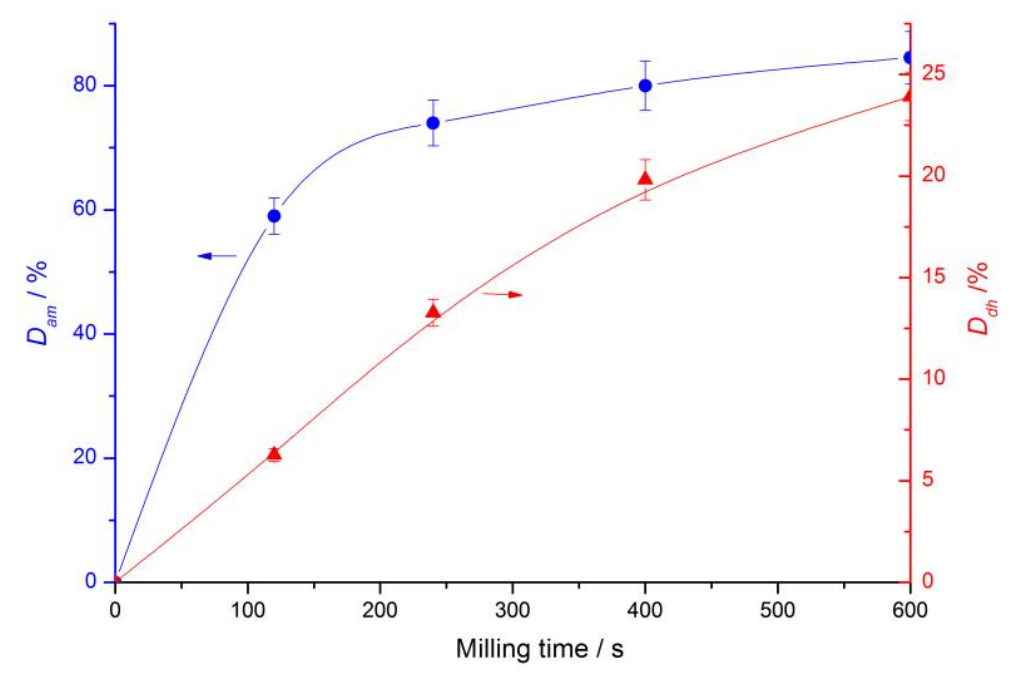

Figure 3. Degree of amorphisation $\left(D_{a m}\right)$ and degree of dehydroxylation $\left(D_{d h}\right)$ of antigorite as a function of milling time (moderate mechanical activation in air).

\subsubsection{Thermal Analysis}

The DTA and TG curves of initial and antigorite subjected to moderate MA in air are presented in Figures 4 and 5, respectively. The endothermic peaks at $\sim 80^{\circ} \mathrm{C}$ correspond to the removal of adsorbed water, and their position was slightly influenced by milling time (Figure 4 ). The endothermic peak at $763{ }^{\circ} \mathrm{C}$ in the DTA spectrum of initial antigorite is due to dehydroxylation of the mineral (the removal of structural water). It was found that MA caused this peak to shift to a lower temperature region. The exothermic peak at $830^{\circ} \mathrm{C}$ corresponds to crystallisation of forsterite and/or enstatite $[7,11,12]$. Its position did not change with increased milling time.

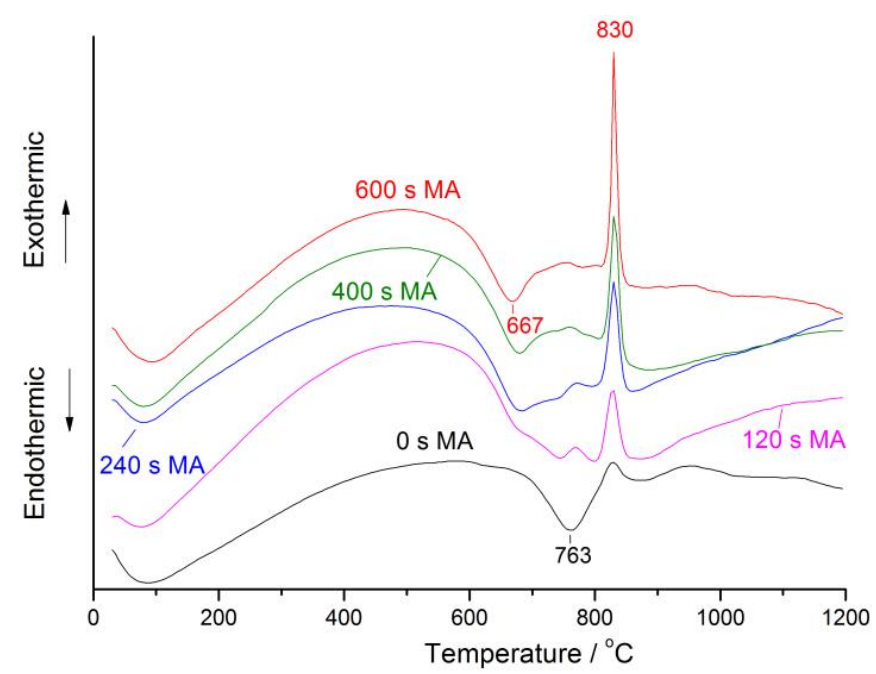

Figure 4. Differential thermal analysis curves for initial antigorite ( $0 \mathrm{~s} \mathrm{MA})$ and mechanically-activated (MA) antigorite (moderate mechanical activation in air).

The overall water loss increased slightly with increased milling time due to mechanosorption of atmospheric moisture and $\mathrm{CO}_{2}$ (Figure 5). The TG data confirmed that disorder of the crystal lattice (Figure 2) led to recombination of structural hydroxyls and their transformation into adsorbed water. As a result, the dehydration reaction accelerated considerably [10,12]. The FT-IR spectra support this, showing decreased intensity of the sharp $\mathrm{OH}$ stretching vibration band at $3675 \mathrm{~cm}^{-1}$ with increased milling time. In contrast, the intensity of a broad band in the $3500-3350 \mathrm{~cm}^{-1}$ region-corresponding to adsorbed water-increased with increased milling times (Figure 6). It is thus conceivable that 
mechanically-induced dehydroxylation could increase the reactivity of milled antigorite in the synthesis of an alkali-activated binder.

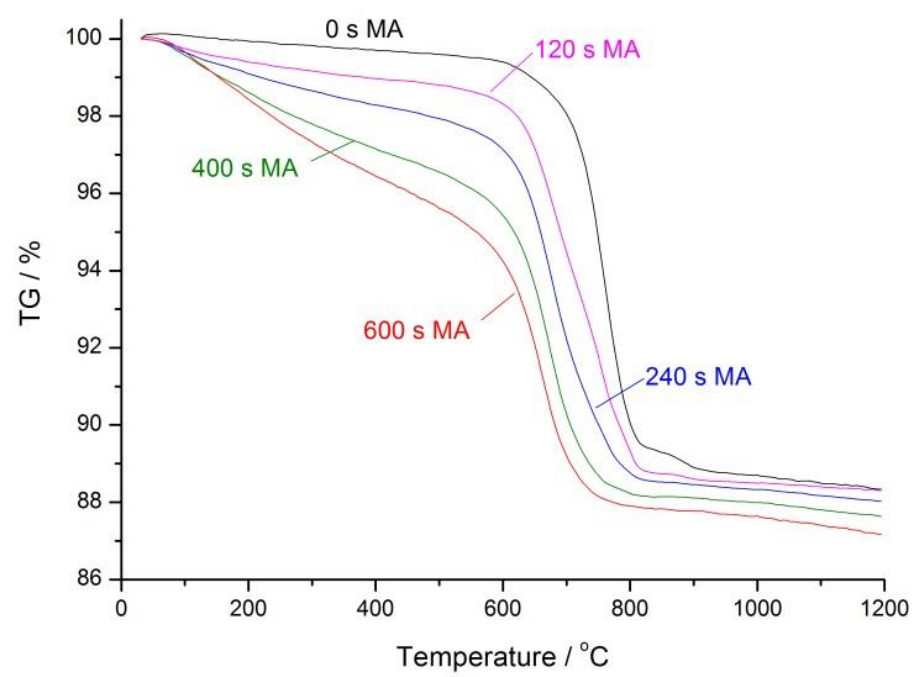

Figure 5. Thermogravity curves for initial and mechanically-activated antigorite (moderate mechanical activation in air).

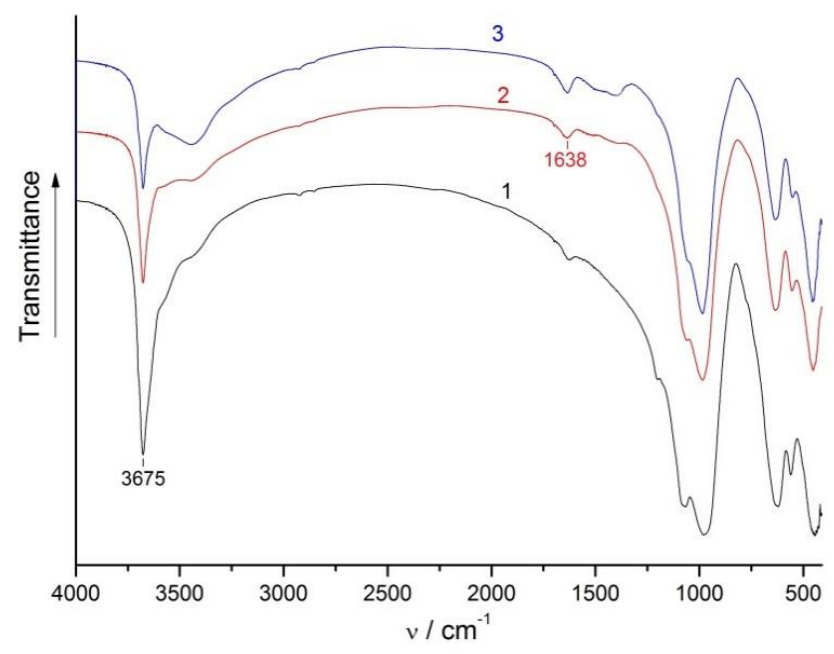

Figure 6. Fourier transform infrared spectra of 1: initial antigorite, 2: antigorite milled in moderate conditions for $600 \mathrm{~s}$ in air, 3: alkali-activated binder prepared using antigorite milled for $600 \mathrm{~s}$ in moderate conditions in air and liquid glass with a modulus of 2.25 (the amount of liquid glass added corresponded to $3 \% \mathrm{Na}_{2} \mathrm{O}$, curing time in dry conditions was 28 days).

The degree of dehydroxylation $\left(D_{d h}\right)$ of antigorite as a function of milling time was estimated from the TG data (Figure 5) using Equation (2):

$$
D_{d h}=\left(1-\frac{W_{M A}}{W_{0}}\right) \cdot 100 \%,
$$

where $W_{0}$ and $W_{M A}$ are the weight losses relative to the temperature range from the onset of the dehydroxylation endotherm (Figure 4) to $1200{ }^{\circ} \mathrm{C}$ for initial and MA antigorite, respectively. From Figure 3, it can be seen that $D_{d h}$ increased almost linearly with increased milling time, reaching $\sim 24 \%$ after 600 s of milling.

The $D_{d h}$ values as functions of $D_{a m}$ were derived from the data shown in Figure 3, and are illustrated in Figure 7. It should be noted that, for vibratory milled antigorite, the peak area of 
(001) reflection and loss of structural water have been determined as functions of milling time in previous publications [10]. We used these data to evaluate $D_{a m}$ and $D_{d h}$ values as described above; the corresponding curve is also shown in Figure 7. Although the MA conditions (type of mill, milling bodies to sample ratio, milling time and so on) are quite different for the two data sets, the resulting curves are very similar. This confirms the close relationship between the disordering of the crystal structure of antigorite and dehydroxylation, regardless of the type of mill used for MA.

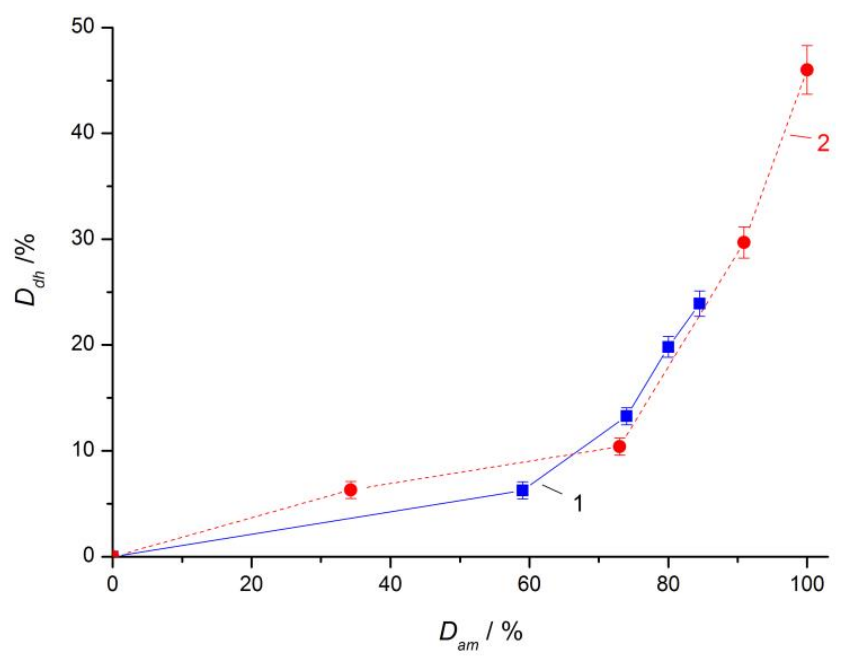

Figure 7. Degree of dehydroxylation as a function of the degree of amorphisation of antigorite from $\mathbf{1}$ : this study (mechanical activation in moderate conditions in air in the planetary mill); and 2: vibratory milling in air [10].

\subsection{Binding Properties of Milled Antigorite and Antigorite-Containing Ore Dressing Tailings}

To estimate the hydraulic activity of antigorite, leaching analyses were performed. The products of complete decomposition of serpentine by $\mathrm{NaOH}$ solution are brucite and soluble sodium silicates [43]. In this study, we carried out alkaline leaching of both antigorite milled in moderate conditions and $\mathrm{AT}$, using 2 or $5 \mathrm{M} \mathrm{NaOH}$. In addition, antigorite milled in air was leached with water. The degree of leaching of $\mathrm{Si}\left(D_{S i}\right)$ was defined by the ratio of silicon in solution to the initial silicon content in antigorite or AT (Figure 8).

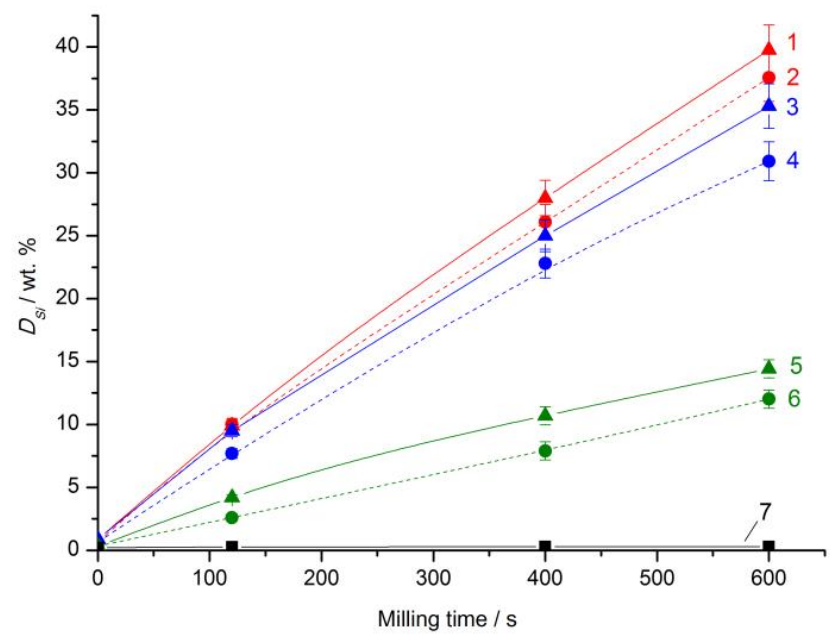

Figure 8. Leaching of silicon $\left(D_{S i}\right)$ from antigorite milled in moderate conditions in air $(1,2)$ and in $\mathrm{CO}_{2}$ $(3,4)$ and from AT milled in air $(5,6)$ as a function of milling time. For curves 1-6, solid and dashed lines designate leaching with $5 \mathrm{M}$ and $2 \mathrm{M} \mathrm{NaOH}$, respectively. For comparison, curve 7 represents leaching of silicon from antigorite milled in moderate conditions in air with water. 
From Figure 8, it can be seen that MA notably enhanced the alkaline leaching of silicon. Following milling in air for $10 \mathrm{~min}$, the $D_{S i}$ values of antigorite samples leached with $2 \mathrm{M}$ and $5 \mathrm{M} \mathrm{NaOH}$ were $37.5 \%$ and $40.0 \%$, respectively. The $D_{S i}$ values of initial antigorite were less than $1 \%$ for all conditions. Leaching of silicon is only slightly affected by the milling atmosphere (air or $\mathrm{CO}_{2}$ ). The leaching of Si from AT (Figure 8, curves 5 and 6) was about 2.5 times lower than that from antigorite in all cases. This is consistent with the $S_{s p}$ values of milled antigorite and AT (Figure 1). This could be due also to the reactivity of talc — which is present in considerable amounts in AT-with $\mathrm{NaOH}$ solution, which is considerably lower than that of antigorite [43].

Another key factor that is known to affect the degree of leaching is structural disorder and the appearance of lattice defects. In the present study, the $D_{S i}$ increased almost linearly with time for antigorite milled in either air or $\mathrm{CO}_{2}$ (Figure 8, curves 1-4), while $S_{s p}$ (Figure 1) and $D_{a m}$ (Figure 3) both exhibited an initial rapid increase but began to plateau during the last $200 \mathrm{~s}$ of milling. Because $D_{a m}$ of antigorite was determined from the peak area corresponding to (001) reflection, it is reasonable to assume that the consistent increase of $D_{S i}$ between the 400 and $600 \mathrm{~s}$ time points (Figure 8 ) is due to the formation of structural defects in directions other than that of the $\mathrm{c}$ axis. The identification of such defects and discussion of their impact on leaching is beyond the scope of this paper. It is pertinent to note that $D_{d h}$ and $D_{S i}$ continuously increased with milling time (Figures 3 and 8 ). The degree of alkaline leaching of silicon from milled antigorite is therefore more strongly associated with $D_{d h}$ of the mineral than with $D_{a m}$ or $S_{s p}$.

Leaching of silicon with water from antigorite milled in air was low, with $D_{S i}$ found to be no more than $0.3 \%$ at all time points (Figure 8 , curve 7 ). However, binders produced using antigorite or AT milled for $600 \mathrm{~s}$ in moderate conditions exhibited a certain cementitious properties even when prepared with only water and alkali activation was not carried out (Table 3). After curing for 28 days in dry conditions, the compressive strengths of the binders based on antigorite or AT milled in air were $3.4 \mathrm{MPa}$ and $7.1 \mathrm{MPa}$, respectively. Due to the different mineral compositions, more water is required to create an antigorite-based paste with suitable workability compared with an AT-based paste. This explains the lower compressive strength of the binder prepared with antigorite.

Table 3. Compressive strengths $(R)$ of binders prepared using water and antigorite or antigorite-containing ore dressing tailings (AT) milled in moderate conditions for $600 \mathrm{~s}$. (w/s: water to solid ratio).

\begin{tabular}{ccccccc}
\hline \multirow{2}{*}{$\begin{array}{c}\text { Mineral } \\
\text { Component }\end{array}$} & $\begin{array}{c}\text { Hardening } \\
\text { Conditions }\end{array}$ & $\begin{array}{c}\text { Milling } \\
\text { Atmosphere }\end{array}$ & w/s & \multicolumn{3}{c}{$\boldsymbol{R}, \mathbf{M P a}$} \\
\cline { 6 - 7 } & & & & $\mathbf{1}$ Day & 7 Days & 28 Days \\
\hline Antigorite & dry & air & 0.35 & 1.8 & 3.4 & 3.4 \\
Antigorite & dry & $\mathrm{CO}_{2}$ & 0.35 & 1.8 & 1.6 & 1.4 \\
Antigorite & humid & air & 0.35 & 1.8 & 2.1 & 2.2 \\
Antigorite & humid & $\mathrm{CO}_{2}$ & 0.35 & 1.4 & 2.8 & 2.4 \\
AT & dry & air & 0.26 & 4.0 & 5.1 & 7.1 \\
AT & dry & $\mathrm{CO}_{2}$ & 0.27 & 4.4 & 6.0 & 8.8 \\
AT & humid & air & 0.26 & 2.5 & 3.5 & 4.7 \\
AT & humid & $\mathrm{CO}_{2}$ & 0.27 & 2.1 & 2.8 & 3.0 \\
\hline
\end{tabular}

It has been established that humid conditions are preferable to dry conditions for curing of thermally-activated serpentine with respect to the mechanical properties of the binder [6]. However, our results indicate that the reverse is true in the case of MA serpentine (Table 3), suggesting that the mechanism of hardening differs between MA and thermally-activated serpentine. The compressive strength was not significantly affected by the milling atmosphere.

The synthesis of alkali-activated binders was investigated by varying the following parameters: milling time, milling atmosphere, amount of liquid glass added and curing conditions (dry or humid). The compressive strength of the alkali-activated binder based on AT milled in air and cured in dry conditions was significantly greater than that of the same binder cured in humid conditions (Figure 9). A similar trend was observed for the binder prepared without alkali activation (Table 3). Compressive 
strength was seen to increase with increased milling time for all samples. The compressive strengths of binders based on initial AT ( 0 s MA) are $1 \mathrm{MPa}$ and $19 \mathrm{MPa}$ for binders cured for 28 days in humid and dry conditions, respectively. The corresponding values for the binders prepared from AT milled for $240 \mathrm{~s}$ in air are $15 \mathrm{MPa}$ and $49 \mathrm{MPa}$, respectively (Figure 9). Using liquid glass with a modulus equal to 3.18 , the best results for compressive strength were achieved when binders were prepared with compositions corresponding to $4 \% \mathrm{Na}_{2} \mathrm{O}$ (Figure 10).

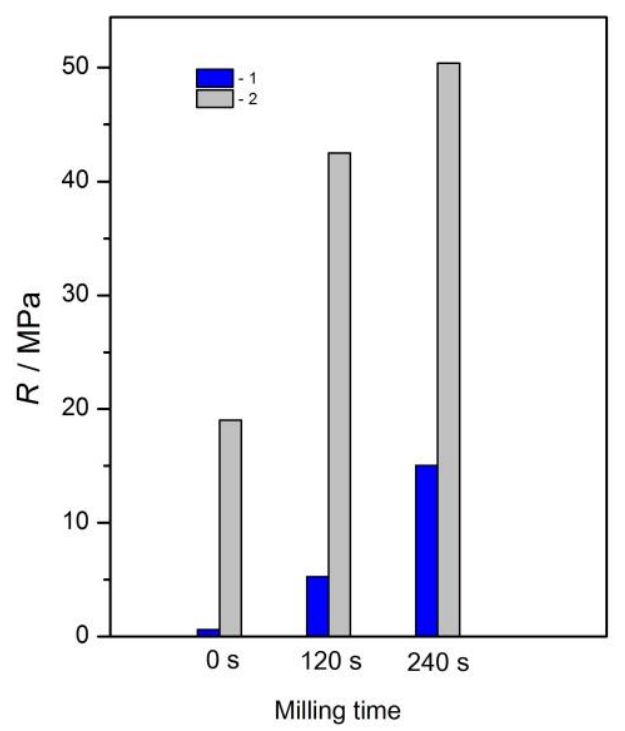

Figure 9. Compressive strength $(R)$ of alkali-activated binders prepared using antigorite-containing ore dressing tailings (AT) milled in air in moderate conditions and liquid glass with a modulus of 3.18. The amount of liquid glass added corresponded to $4 \% \mathrm{Na}_{2} \mathrm{O}$. Curing time was 28 days. Hardening conditions were 1: humid, or 2: dry.

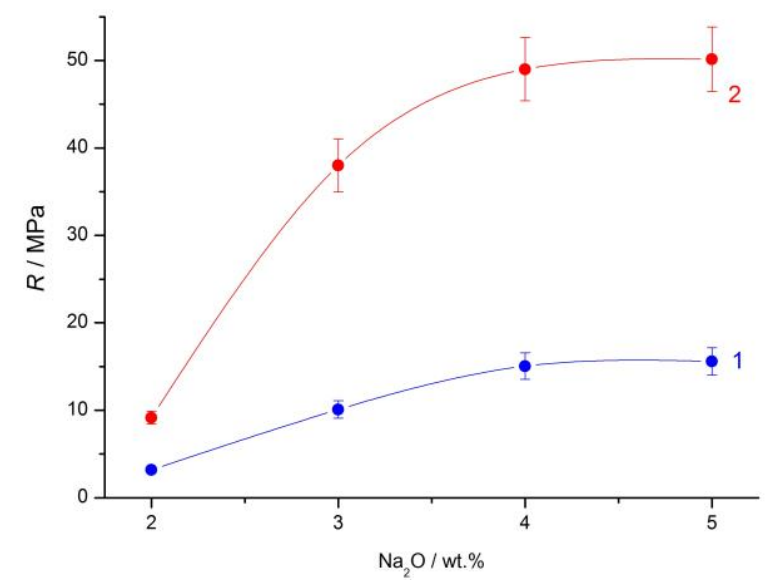

Figure 10. Compressive strengths $(R)$ of alkali-activated binders prepared using antigorite-containing ore dressing tailings (AT) milled in air in moderate conditions for $240 \mathrm{~s}$ as a function of amount of added liquid glass. The modulus of liquid glass was 3.18. Curing time was 28 days. Hardening conditions were 1: humid, or 2: dry.

Table 4 presents the compressive strengths of alkali-activated binders prepared using liquid glass with a modulus of 2.25 (the amount of liquid glass added corresponded to $3 \% \mathrm{Na}_{2} \mathrm{O}$ ) and antigorite or AT milled in air or in $\mathrm{CO}_{2}$ for $600 \mathrm{~s}$ and cured in dry or humid conditions. After curing for 28 days in dry conditions, the compressive strength of the binders based on antigorite and AT milled in air were $40.8 \mathrm{MPa}$ and $30.8 \mathrm{MPa}$, respectively. The corresponding compressive strengths of binders based on antigorite and AT milled in $\mathrm{CO}_{2}$ were $29.1 \mathrm{MPa}$ and $23.0 \mathrm{MPa}$, respectively. The increased compressive 
strength of the binders based on antigorite cured in dry conditions compared with those based on AT is consistent with the alkali-leaching experiments (Figure 8).

Table 4. Compressive strengths $(R)$ of alkali-activated binders prepared using antigorite or antigoritecontaining ore dressing tailings (AT) milled for $600 \mathrm{~s}$ in moderate conditions and liquid glass with a modulus of 2.25. The specific surface area $\left(S_{s p}{ }^{(\mathrm{B})}\right)$ was measured using the Blaine method. The amount of liquid glass added corresponded to $3 \% \mathrm{Na}_{2} \mathrm{O}$. (w/s: water to solid ratio).

\begin{tabular}{cccccccc}
\hline $\begin{array}{c}\text { Mineral } \\
\text { Component }\end{array}$ & $\begin{array}{c}\boldsymbol{S}_{\boldsymbol{s p}}{ }^{(\mathbf{B})}, \\
\mathbf{m}^{\mathbf{2}} \mathbf{k g}\end{array}$ & $\begin{array}{c}\text { Hardening } \\
\text { Conditions }\end{array}$ & $\begin{array}{c}\text { Milling } \\
\text { Atmosphere }\end{array}$ & w/s & \multicolumn{3}{c}{$\boldsymbol{R}, \mathbf{M P a}$} \\
\cline { 6 - 8 } & & & & 1 Day & 7 Days & 28 Days \\
\hline Antigorite & 1259 & dry & air & 0.26 & 12.2 & 20.6 & 40.8 \\
Antigorite & 1255 & dry & $\mathrm{CO}_{2}$ & 0.25 & 15.6 & 28.0 & 29.1 \\
Antigorite & 1259 & humid & air & 0.26 & 3.5 & 4.1 & 5.3 \\
Antigorite & 1255 & humid & $\mathrm{CO}_{2}$ & 0.25 & 5.0 & 6.7 & 6.8 \\
AT & 1280 & dry & air & 0.22 & 10.8 & 22.6 & 30.8 \\
AT & 1288 & dry & $\mathrm{CO}_{2}$ & 0.25 & 10.2 & 21.8 & 23.0 \\
AT & 1280 & humid & air & 0.22 & 6.8 & 8.7 & 7.8 \\
AT & 1288 & humid & $\mathrm{CO}_{2}$ & 0.25 & 1.3 & 1.9 & 2.0 \\
\hline
\end{tabular}

From Table 4, it can be seen that $\mathrm{MA}$ in $\mathrm{CO}_{2}$ is not preferable to air to achieve high compressive strengths, as has been described for magnesia ferriferous slag [41]. However, the compressive strengths of binders prepared following MA in $\mathrm{CO}_{2}$ - particularly in the case of AT cured in dry conditions-were similar to those prepared from mineral component that had been milled in air. This suggests that serpentinite tailings milled in $\mathrm{CO}_{2}$, which is carried out for $\mathrm{CO}_{2}$ capture, could be used to produce alkali-activated binders.

The XRD data revealed no newly formed crystalline compounds in the binder prepared using liquid glass and antigorite milled in air and cured in dry conditions (Figure 11). Consequently, the cementitious phase is likely amorphous in nature. FT-IR spectrum of this binder is shown in Figure 6. When this FT-IR spectrum is compared with that of the milled antigorite (Figure 6), it is apparent that the intensities of the $\mathrm{OH}$ stretching vibration band in the $3500-3350 \mathrm{~cm}^{-1}$ region and the $\mathrm{OH}$ bending vibration band at $1638 \mathrm{~cm}^{-1}$ increased, suggesting that the notable hydration of antigorite occurred. The FT-IR spectrum of the binder shows increased intensity of the carbonate group stretching vibration band in the $1550-1350 \mathrm{~cm}^{-1}$ region due to chemisorption of the atmospheric carbon dioxide.

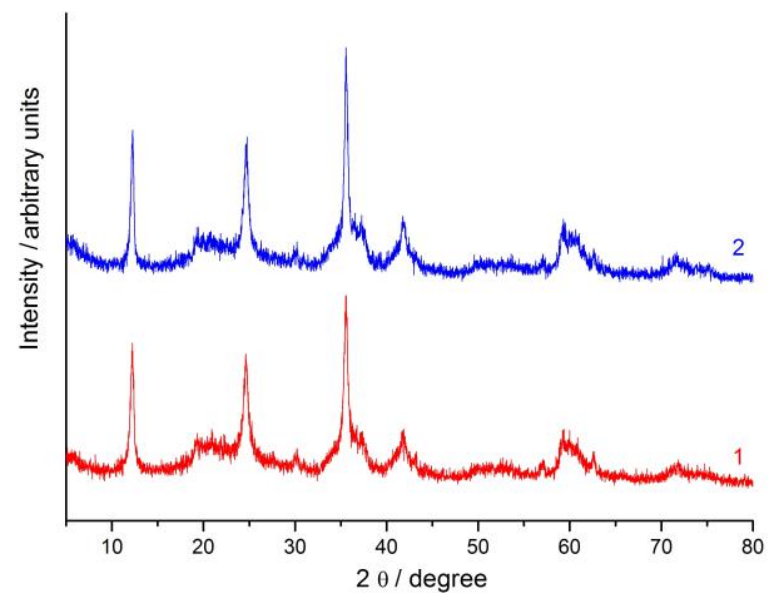

Figure 11. The X-ray diffraction patterns of 1: antigorite milled in moderate conditions for $600 \mathrm{~s}$ in air, 2: alkali-activated binder prepared using antigorite milled for $600 \mathrm{~s}$ in moderate conditions in air and liquid glass with a modulus of 2.25 (the amount of liquid glass added corresponded to $3 \% \mathrm{Na}_{2} \mathrm{O}$, curing time in dry conditions was 28 days). 


\section{Conclusions}

From our results, we can draw the following conclusions:

1. The $S_{s p}$ of antigorite milled in a planetary mill in air is 30-40\% greater than that of AT milled in equivalent conditions. This can be explained by the difference in the mineral compositions of antigorite and AT. The atmosphere of MA (air or $\mathrm{CO}_{2}$ ) affects the $S_{s p}$ of antigorite, although to a lesser extent than the choice of mineral component.

2. Milling of antigorite in a planetary mill results in rapid amorphisation. The $D_{a m}$ along the c axis reached $85 \%$ after MA for $600 \mathrm{~s}$ in air in moderate conditions.

3. According to thermal analysis and FT-IR data, milling of antigorite leads to dehydroxylation. After $600 \mathrm{~s}$ of milling in air, the $D_{d h}$ of antigorite was $24 \%$. Comparison of our results with literature data confirms that dehydroxylation of MA antigorite is closely related to its amorphisation, irrespective of the type of mill that is used.

4. Mechanical activation of antigorite increases the alkaline leaching of Si into solution. The degree of silicon leaching for antigorite milled in air for $600 \mathrm{~s}$ and leached with $5 \mathrm{M} \mathrm{NaOH}$ was $40 \%$. The corresponding value for initial antigorite was less than $1 \%$. Water leaching of silicon from antigorite milled in air for $600 \mathrm{~s}$ resulted in leaching of only $0.3 \%$ of silicon. The degree of alkaline leaching of silicon from MA antigorite is more significantly associated with the $D_{d h}$ of the mineral than with $D_{a m}$ or $S_{s p}$.

5. The reduced alkali leaching of Si from milled AT compared with that from milled antigorite can be explained by the differences in $S_{s p}$ of the solid components, and by the lower reactivity of talc, as one of the main admixtures in $\mathrm{AT}$, with a $\mathrm{NaOH}$ solution compared with that of antigorite.

6. Binders prepared using antigorite or AT that have been milled for $600 \mathrm{~s}$ in moderate conditions in air and in $\mathrm{CO}_{2}$ show cementitious properties even if the paste is prepared without the use of alkali. The compressive strengths of the binders based on antigorite or AT milled in air for $600 \mathrm{~s}$ and cured for 28 days in dry conditions were found to be $\sim 3 \mathrm{MPa}$ and $\sim 7 \mathrm{MPa}$, respectively. The lower compressive strength of the binder based on milled antigorite was concluded to be related to the higher water demand of the mineral.

7. The cementitious properties of alkali-activated binder increased with increasing milling time of the antigorite. Alkali-activated binder that was prepared using liquid glass and cured at dry conditions produced a preferable product compared with that cured in humid conditions. The compressive strength of the alkali-activated binder based on AT milled in air for $240 \mathrm{~s}$ and cured for 28 days in dry or humid conditions was $49 \mathrm{MPa}$ and $15 \mathrm{MPa}$, respectively. The corresponding values for binders prepared using initial AT were $19 \mathrm{MPa}$ and $1 \mathrm{MPa}$, respectively.

8. In line with the mineral compositions of antigorite and AT and the results of leaching experiments, alkali-activated binders based on milled antigorite and cured at dry conditions show higher compressive strengths than those based on AT. According to XRD data, the cementitious phase is amorphous in nature. The milling atmosphere (air or $\mathrm{CO}_{2}$ ) has a relatively small effect on the cementitious properties of alkali-activated binders.

Author Contributions: Designing the study, E.V.K., B.I.G. and A.M.K.; pre-treatment of mineral components, preparation and characterisation of binders, B.I.G.; Thermal analysis and leaching experiments, E.V.K.; FT-IR and XRD studies, A.M.K.; Writing the initial draft of the paper, E.V.K. and B.I.G.; Writing the final paper, A.M.K.

Funding: This research received no external funding.

Acknowledgments: The authors are thankful to E.S. Serova and A.G. Ivanova for help with experimental work. Conflicts of Interest: The authors declare no conflict of interest. 


\section{References}

1. Wicks, F.J.; O'Hanley, D.S. Serpentine minerals: structures and petrology. Rev. Miner. Geochem. 1988, 19, 91-167.

2. Barnes, S.-J.; Melezhik, V.A.; Sokolov, S.V. The composition and mode of formation of the Pechenga nickel deposits, Kola Peninsula, North Western Russia. Can. Mineral. 2001, 39, 447-471. [CrossRef]

3. Hitch, M.; Ballantyne, S.M.; Hindle, S.R. Revaluing mine waste rock for carbon capture and storage. Int. J. Min. Reclam. Environ. 2010, 24, 64-79. [CrossRef]

4. Svetlov, A.; Makarov, D.; Vigdergauz, V. Nonoxidative leaching of non-ferrous metals from wastes of Kola Mining by sulphuric acid. Int. J. Min. Sci. 2015, 1, 17-24.

5. Masloboev, V.A.; Makarov, D.V.; Baklanov, A.A.; Amosov, P.V.; Seleznev, S.G. Methods to reduce the environmental hazards of mining and processing of minerals in the Arctic regions. In Proceedings of the International Mineral Processing Congress 2016 XXVIII, Quebec City, QC, Canada, 11-15 September 2016.

6. Budnikov, P.P.; Mchedlov-Petrosyan, O.P. Manifestation of hydraulic binding properties by dehydrated serpentinite. Dokl. Akad. Nauk SSSR 1950, 73, 539-540. (In Russian)

7. Dlugogorski, B.Z.; Balucan, R.D. Dehydroxylation of serpentine minerals: Implications for mineral carbonation. Renu. Sust. Energy Rev. 2014, 31, 353-367. [CrossRef]

8. Li, J.; Hitch, M.; Power, I.M.; Pan, Y. Integrated mineral carbonation of ultramafic mine deposits-A review. Minerals 2018, 8, 147-164. [CrossRef]

9. Li, J.; Hitch, M. Ultra-fine grinding and mechanical activation of mine waste rock using a high-speed stirred mill for mineral carbonation. Int. J. Min. Met. Mater. 2015, 22, 1005-1016. [CrossRef]

10. Drief, A.; Nieto, F. The effect of dry grinding on antigorite from Mulhacen, Spain. Clay Clay Min. 1999, 47, 417-424. [CrossRef]

11. Kim, D.J.; Sohn, J.S.; Ahn, J.G.; Chung, H.S. Extraction of metals from mechanically milled serpentine. Geosyst. Eng. 2008, 11, 25-28. [CrossRef]

12. Zhang, Q.; Sugiyama, K.; Saito, F. Enhancement of acid extraction of magnesium and silicon from serpentine by mechanochemical treatment. Hydrometallurgy 1997, 45, 323-331. [CrossRef]

13. Brice, D.G.; Lesley, S.-L.; Provis, J.L.; van Deventer, J.S.J. Conclusions and the future of alkali activation technology. In Alkali-Activated Materials: State of the Art Report of RILEM TC 224-AAM; Provis, J.L., van Deventer, J.S.J., Eds.; Springer Science \& Business Media: Dordrecht, Holland, 2014; pp. 381-388.

14. Shi, C.; Krivenko, P.V.; Roy, D.M. Alkali-Activated Cements and Concretes; CRC Press: Boca Raton, FL, USA, 2006; p. 376.

15. Provis, J.L.; Palomo, A.; Shi, C. Advances in understanding alkali-activated materials. Cem. Concr. Res. 2015, 78A, 110-125. [CrossRef]

16. Part, W.K.; Ramli, M.; Cheah, C.B. An overview on the influence of various factors on the properties of geopolymer concrete derived from industrial by-products. Constr. Build. Mater. 2015, 77, 370-395. [CrossRef]

17. Provis, J.L.; Bernal, S.A. Geopolymers and related alkali-activated materials. Annu. Rev. Mater. Res. 2014, 44, 299-327. [CrossRef]

18. Ke, X.; Criado, M.; John, L.; Provis, J.L.; Bernal, S.A. Slag-Based Cements That Resist Damage Induced by Carbon Dioxide. ACS Sustain. Chem. Eng. 2018, 6, 5067-5075. [CrossRef]

19. Mucsi, G.; Kumar, S.; Csőke, B.; Kumar, R.; Molnár, Z.; Rácz, Á.; Mádai, F.; Debreczeni, Á. Control of geopolymer properties by grinding of land filled fly ash. Int. J. Min. Proc. 2015, 143, 50-58. [CrossRef]

20. Nath, S.K.; Maitra, S.; Mukherjee, S.; Kumar, S. Microstructural and morphological evolution of fly ash based geopolymers. Constr. Build. Mater. 2016, 111, 758-765. [CrossRef]

21. Ma, C.-K.; Awang, A.Z.; Omar, W. Structural and material performance of geopolymer concrete: A review. Constr. Build. Mater. 2018, 186, 90-102. [CrossRef]

22. Arbi, K.; Nedeljković, M.; Zuo, Y.; Ye, G. A Review on the Durability of Alkali-Activated Fly Ash/Slag Systems: Advances, Issues, and Perspectives. Eng. Chem. Res. 2016, 55, 5439-5453. [CrossRef]

23. Ding, Y.; Dai, J.-G.; Shi, C.-J. Mechanical properties of alkali-activated concrete: A state-of-the-art review. Constr. Build. Mater. 2016, 127, 68-79. [CrossRef]

24. Luukkonen, T.; Abdollahnejad, Z.; Juho Yliniemi, J.; Kinnunen, P.; Illikainen, M. One-part alkali-activated materials: A review. Cem. Concr. Res. 2018, 103, 21-34. [CrossRef]

25. Heinicke, G. Tribochemistry; Akademie-Verlag: Berlin, Germany, 1984; p. 495. 
26. Avvakumov, E.G. Mechanical Methods of Activation of Chemical Processes; Nauka: Novosibirsk, Russia, 1986; p. 306. (In Russian)

27. Boldyrev, V.V. Mechanochemistry and mechanical activation of solids. Russ. Chem. Rev. 2006, 75, 177-189. [CrossRef]

28. Baláž, P. Mechanochemistry in Nanoscience and Minerals Engineering; Springer: Heidelberg, Germany, 2008; p. 413.

29. Tchadjie, L.N.; Ekolu, S.O. Enhancing the reactivity of aluminosilicate materials toward geopolymer synthesis. J. Mater. Sci. 2018, 53, 4709-4733. [CrossRef]

30. Kumar, S.; Kumar, R. Mechanical activation of fly ash: effect on reaction, structure and properties of resulting geopolymer. Ceram. Int. 2011, 37, 533-541. [CrossRef]

31. Djobo, J.N.Y.; Elimbi, A.; Tchakoute, H.K.; Kumar, S. Mechanical activation of volcanic ash for geopolymer synthesis: Effect on reaction kinetics, gel characteristics, physical and mechanical properties. RSC Adv. 2016, 6, 39106-39117. [CrossRef]

32. Wei, B.; Zhang, Y.; Bao, S. Preparation of geopolymers from vanadium tailings by mechanical activation. Constr. Build. Mater. 2017, 145, 236-242. [CrossRef]

33. Mucsi, G. Mechanical activation of power station fly ash by grinding: a review. J. Silic. Based Compos. Mater. 2016, 68, 56-61.

34. Marjanovic, N.; Komljenovic, M.; Bascarevic, Z.; Nikolic, V. Improving reactivity of fly ash and properties of ensuing geopolymers through mechanical activation. Constr. Build. Mater. 2014, 57, 151-162. [CrossRef]

35. Temuujin, J.; Williams, R.P.A.; van Riessen, A. Effect of mechanical activation of fly ash on the properties of geopolymer cured at ambient temperature. J. Mater. Process. Technol. 2009, 209, 5276-5280. [CrossRef]

36. Kalinkina, E.V.; Kalinkin, A.M.; Forsling, W.; Makarov, V.N. Sorption of atmospheric carbon dioxide and structural changes of $\mathrm{Ca}$ and $\mathrm{Mg}$ silicate minerals during grinding. I. Diopside. Int. J. Miner. Process. 2001, 61, 273-288. [CrossRef]

37. Kalinkina, E.V.; Kalinkin, A.M.; Vasil'eva, T.N.; Mazukhina, S.I.; Belyaevskii, A.T. Study of the mechanically activated serpentine's sorption properties in respect to copper (II) cations. Geoekologiya 2012, 3, 229-236. (In Russian)

38. Kalinkin, A.M.; Kalinkina, E.V.; Politov, A.A.; Makarov, V.N.; Boldyrev, V.V. Mechanical interaction of Ca silicate and aluminosilicate minerals with $\mathrm{CO}_{2}$. J. Mater. Sci. 2004, 39, 5393-5398. [CrossRef]

39. Turianicová, E.; Obut, A.; Tuček, L.; Zorkovská, A. Interaction of natural and thermally processed vermiculites with gaseous carbon dioxide during mechanical activation. Appl. Clay Sci. 2014, 88-89, 86-91. [CrossRef]

40. Turianicová, E. $\mathrm{CO}_{2}$ utilization for mechanochemical carbonation of celestine. GeoSci. Eng. 2015, 6, $20-23$. [CrossRef]

41. Kalinkin, A.M.; Kumar, S.; Gurevich, B.I.; Alex, T.C.; Kalinkina, E.V.; Tyukavkina, V.V.; Kalinnikov, V.T.; Kumar, R. Geopolymerization behavior of $\mathrm{Cu}-\mathrm{Ni}$ slag mechanically activated in air and in $\mathrm{CO}_{2}$ atmosphere. Int. J. Miner. Process. 2012, 112-113, 101-106. [CrossRef]

42. Khodakov, G.S. Physics of Grinding; Nauka: Moscow, Russia, 1972; p. 307. (In Russian)

43. Vlasov, V.V.; Remiznikova, V.I. On interaction of clay minerals and some sheet silicates with alkaline solutions. In XRD Studies on Mineral Raw Materials; Sidorenko, G.A., Ed.; Nedra: Moscow, Russia, 1967; p. 140. (In Russian)

(C) 2018 by the authors. Licensee MDPI, Basel, Switzerland. This article is an open access article distributed under the terms and conditions of the Creative Commons Attribution (CC BY) license (http://creativecommons.org/licenses/by/4.0/). 